\title{
Growth hormone locus polymorphism in Ongole Grade and Fries Holland Grade bulls and its implications in the digestibility of feed
}

\author{
S. Maylinda* and W. Busono \\ Faculty of Animal Husbandry, University of Brawijaya, Jl. Veteran No. 1, \\ Malang, East Java 65145 - Indonesia \\ *CorrespondingE-mail : sucik@ub.ac.id
}

Received January 09, 2020; Accepted May 15, 2020

\begin{abstract}
ABSTRAK
Penelitian ini bertujuan untuk menganalisis polimorfisme gen hormon pertumbuhan (GH) dan implikasinya terhadap daya cerna pakan berkualitas rendah dan tinggi. 40 sapi jantan dari Peranakan Ongole (Ongole Grade/ OG) dan 30 dari Peranakan Fries Holland (Fries Holland Grade/ FHG) digunakan sebagai subjek penelitian untuk mengukur pertambahan berat badan, komsumsi pakan, efisiensi pakan dan daya cerna terhadap pakan. Perlakuan berupa pakan sumber serat dari berbagai tanaman dengan berat $15 \%$ (P1: kualitas rendah) dan 22,5\% dari total pakan (P2: kualitas tinggi). Gen GH sepanjang 329 bp diamplifikasi ( $\mathrm{F}=$ 5'-CCCACGGGAGAGAATGAGGC-3'; dan $\mathrm{R}=5^{\prime}$ TGAGGAACTGCAGGGGGPA-3') dan dipotong menggunakan enzim restriksi Msp1. Tingkat polimorfisme antara sapi OG dan FHG mencapai 45\%. Pertambahan berat badan sapi FHG menunjukkan lebih tinggi secara signifikan dibandingkan OG $(\mathrm{P}<0,05)$ pada minggu pertama hingga ketiga namun menjadi tidak berbeda pada minggu keempat. Dapat disimpulkan bahwa tingkat polimorfisme antara sapi jantan OG dan FHG adalah tinggi, serta sapi jantan FHG memiliki respon pertumbuhan dan efisiensi penggunaan pakan yang lebih tinggi dibandingkan OC.
\end{abstract}

Kata kunci : hormon pertumbuhan, kecernaan pakan, polimorfisme

\section{ABSTRACT}

This research aimed to analyze polymorphism of the growth hormone $(\mathrm{GH})$ gene and its implication on digestibility of low and high quality feed. Forty bulls Ongole Grade (OG) and 30 bulls Fries Holland Grade (FHG) had been selected and subjected for an experiment to measure body weight gain, dry matter intake, feed efficiency and feed digestibility. The treatment was crude fibrous feed from various plants with a fibre weight of $15 \%$ (P1: low quality) and 22.5\% (P2: high quality). The $389 \mathrm{bp}$ of $\mathrm{GH}$ gene was amplified ( $\mathrm{F}=$ 5'-CCCACGGGAGAGAATGAGGC-3'; dan $\mathrm{R}=5^{\prime}$ TGAGGAACTGCAGGGGGPA-3') and digested using Msp1 restriction enzyme. Polymorphism between OC and HFC bulls was $45 \%$. The FHG bulls' weight gain were significantly higher than of OC $(\mathrm{P}<0.05)$ at first to third week, but become similar $(\mathrm{P}>0.05)$ at fourth week. It was concluded that the polymorphism between FHG and OC was high and HFC have a growth response and feed efficiency higher than those of OC.

Keywords : dry matter, feed digestibility, growth hormone, polymorphism. 


\section{INTRODUCTION}

Challenges in the livestock sector are increasing, and development goals include the targets of consumption and improving the welfare of farmers. Beef products consumption per capita from 2011 to 2014 had tended to decrease, compared to poultry/broiler meat products which had tended to increase continuously every year. The consumption in 2011 was $0.417 \mathrm{~kg}$ per capita and had came the lowest $(0.261 \mathrm{~kg})$ in 2014 (General Directorate of Livestok, 2017). Furthermore, the beef contribution to fulfill national meat consumption also decreased each year (Lehtonen and Irz, 2013).

The domestic market requires 490,000 tons of meat in every year, equivalent to 1.4 million heads beef cattle with on average live-weight of $350 \mathrm{~kg}$ per head. Considerable effort is required to increase the production of meat, and it has to be at the same pace with the increase in population; this can be achieved by seeking the optimal level of production by local farms. Local farms can only provide 350,000 tons of meat, while the rest is fulfilled by imports in the form of fattened beef cattle and beef (Ferraz and Felicio, 2010). If the ability of local beef production is not increased in line with population growth, the imports will rise and the local breeder revenue will decline.

The production of meat can be improved through the livestock feed. Rice straw and corn straw as common feed has low quality because crude fiber content is high and hard to digest. Local breeders usually add feed supplements to complement the nutrition in the feed to overcome that problem. However, if a particular beef cattle breed is able to digest low quality feed and turn it into good quality meat, they will be useful in fulfilling the escalating demand for beef (Nazli et al., 2018). The ability of livestock to produce good-quality meat is manifestation of its genetic material to respond to the environment, including feed. It has been reported that imported livestock, which have good performance in their respective country, exhibit worse performance in the tropical environment with low quality feed (Colditz and Hine, 2016).

There are several beef cattle breeds in Indonesia, such as Bali, Grati, Madura, and Ongole Grade. Local beef cattle usually have better adaptation to the poor environment than imported breeds. It was reported by Pribadi et al. (2015) that reproductive performances of Bali cattle is better than crossing between female Bali cattle and Simmental cattle, it was revealed by days open of Bali cattle was shorter (around 80 days in Bali cattle vs more than 100 days in it's crossing). On the other hand, in other research was also reported that Ongole Grade crossed have better rice straw fermented digestion than of Ongole Grade (Purbowati, et al., 2005). The research to study the effect of cattle breed on the performance (production, reproduction, feed digestion) is important to be done. It have better for choosing the most adaptable breed is the strategic move in order to increase beef cattle productivity. Breed selection is important, but complicated and time-consuming process (Oldenbroek and van der Waaij, 2014). Therefore, Indonesian breeders, especially the traditional ones, rarely practice this procedure. Nowadays, new technology to aid early selection has emerged. This technology is based on the use of unique genetic markers which make it possible to distinguish the superior cattle from the inferior cattle at the earliest possible stage, allowing the breeder to avoid rearing unproductive animals (Amiri et al., 2018). The implementation of genetic marker technology in the selection process will increase the genetic quality in the cattle; indeed it has been demonstrated that Marker Assisted Selection (MAS) improves the genetic quality of cattle up to $30 \%$ (Wakchaure et al., 2015). This research aimed to develop an early selection method based on genetic markers which reflect the ability of the cattle to digest lowquality feed.

\section{MATERIALS AND METHODS}

\section{Feed treatments and variables}

Forty Ongole Grade $(O G)$ and thirty Fries Holland Grade (FHG) bulls were subjected for this research. The treatment was crude fibrous feed containing dry straw and leaves waste from paddy (Oryza sativa), maize (Zea mays), cassava (Manihot utilissima), and elephant grass (Pennisetum purpureum). In prior to treatment, proximate analysis was conducted. The treatment consisted of two types of crude fibrous feed, i.e. fibre with weight of $15 \%$ (P1: low quality) and $22.5 \%$ (P2: high quality). Those types of feed had been given regularly everyday for a month. Observation was conducted every week including weight gain, dry matter consumption, and efficiency but the digestibility was measured at the first and fourth week. 


\section{Polymorphism Analysis}

DNA was isolated from blood collected from the jugular vein from each subject by using a venoject. The amplification target was growth hormone $(\mathrm{GH})$ fragment in the 3' intron region and the DGAT1 gene in exon VIII. This procedure was using primers $\mathrm{F}=5^{\prime}-$ CCCACGGGCAAGAATGAGGC-3' and R = 5'TGAGGAACTGCAGGGGCCCA- 3', with length $329 \mathrm{bp}$. A thermal cycler was used to perform amplification with configurations. Amplicon was followed by $2 \%$ agarose gel electrophoresis to validate the amplification result. Each PCR product was digested with Msp1 restriction enzyme (GH gene) at $37^{\circ} \mathrm{C}$ for 3 hours (Putra et al., 2014). The digested result was checked by $2 \%$ agarose gel electrophoresis. The GH gene polymorphism was determined by the formula (Nurdianawati et al., 2016):

$\mathrm{PIC}_{\mathrm{i}}=1-\Sigma \mathrm{p}_{\mathrm{ij}}^{2}$

Where : PIC: polymorphic information content of $\mathrm{i}$ locus; $\Sigma \mathrm{p}_{\mathrm{ij}}^{2}$ is $\mathrm{j}$ allele frequency of $\mathrm{i}$ locus.

The formula below was used to calculate allele frequency:

$$
\begin{aligned}
& \mathrm{p}=[2(\mathrm{AA})+(\mathrm{AB})] / 2 \mathrm{~N} \\
& \mathrm{q}=[2(\mathrm{BB})+(\mathrm{AB})] / 2 \mathrm{~N}
\end{aligned}
$$

Where $\mathrm{p}$ is the frequency of A allele, and $q$ is the frequency of $\mathrm{B}$ allele. AA is the number of AA genotype, $\mathrm{BB}$ is the number of $\mathrm{BB}$ genotype, and $\mathrm{AB}$ is the number of $\mathrm{AB}$ genotype. $\mathrm{N}$ is the total number of individuals (Jakaria and Noor, 2011).

\section{RESULTS}

\section{Daily Weight Gain}

The daily weight gains of both breeds from the beginning of the study until the first week were significantly different, either from the first week to the second week $(\mathrm{P}<0.05)$. Daily weight gains for different treatments within each of the breeds were basically the same from the second to third weeks although different breeds still demonstrated significantly different $(\mathrm{p}<0.05)$ daily weight gains compared to each other. FHG and OG bulls exhibited the same daily growth while comparing feed treatments still have a significant $(\mathrm{P}<0.05)$ result (Table 1). The interaction between breed and treatment was nearly significant $(\mathrm{P}<0.05)$. Nevertheless, the mean value of daily growth was affected by breed and treatment separately, while breed and treatment were not affecting each other (Table 2).

Table 1. The Influence of Breed Types, Treatments, and the Interactions on Weight Gain (kg) at the First Week

\begin{tabular}{clccc}
\hline & Breed & High-quality feeds & Low-quality feeds & Mean *) \\
\hline \multirow{3}{*}{ First week } & OG, kg & -3.23 & 4.33 & $0.52^{\mathrm{a}}$ \\
& FHG, kg & 7.33 & 12.33 & $9.83^{\mathrm{b}}$ \\
& Mean **) & $1.27^{\mathrm{a}}$ & $7.76^{\mathrm{b}}$ & \\
& OG, kg & -2.15 & 9.67 & $-0.05^{\mathrm{a}}$ \\
\multirow{3}{*}{ Second week } & FHG, kg & 6.80 & 9.67 & $8.23^{\mathrm{b}}$ \\
& Mean **) & $1.69^{\mathrm{a}}$ & $5.31^{\mathrm{b}}$ & \\
& OG, kg & 5.89 & 0.15 & $2.98^{\mathrm{a}}$ \\
\multirow{2}{*}{ Third week } & FHG, kg & 12.80 & 13.87 & $13.34^{\mathrm{b}}$ \\
& Mean **) & $8.90^{\mathrm{a}}$ & $6.11^{\mathrm{a}}$ & \\
& OG, kg & $0.19^{\mathrm{a}}$ & $0.67^{\mathrm{a}}$ & 0.43 \\
& FHG, kg & $0.53^{\mathrm{b}}$ & $0.55^{\mathrm{a}}$ & 0.54 \\
& Mean **) & $0.31^{\mathrm{a}}$ & $0.62^{\mathrm{b}}$ & \\
\hline
\end{tabular}

OG ; Ongole Grade; FHG: Fries Holland Grade; *) mean based on breed type; **) mean based on each treatment; values followed by different superscript at the same column $(*)$ or row $(* *)$ show significantly different at $5 \%$. 


\section{Dry Matter Consumption}

Table 3 showed that FHG bulls consumed significantly $(\mathrm{P}<0.05)$ more dry matter than $\mathrm{OG}$ bulls (10.14 $\mathrm{kg}$ and $4.65 \mathrm{~kg}$ per day, respectively). This may be correlated with the fact that the mean starting weight for the different breeds was significantly different $(\mathrm{P}<0.05)$ in the first place (FHG weighed $349 \mathrm{~kg}$, whereas OG weighed only $265 \mathrm{~kg}$ ) (Data not showed).

\section{Feeding efficiency}

Feeding efficiency was calculated by dividing mean daily growth by dry matter consumption. Breed strongly affected the feeding efficiency $(\mathrm{P}<0.05)$, but feeding treatment did not have a significant effect (Table 4). This experiment produced different results compared with other similar studies. The current understanding is that OG bulls should have high adaptability to low-quality feed compared with other bull breeds.

\section{Growth Hormone (GH) Polymorphism}

Polymorphic information content (PIC) for

Table 2. The Influence of Breed Types, Treatments, and the Interactions on Weight Gain (kg) (Mean for All Week)

\begin{tabular}{|c|c|c|c|}
\hline Breeds & High-quality feed & Low-quality feed & Mean * \\
\hline OG & 0.08 & 0.27 & $0.17^{\mathrm{a}}$ \\
\hline FHG & 0.56 & 0.71 & $0.63^{\mathrm{b}}$ \\
\hline Mean ** & $0.28^{\mathrm{a}}$ & $0.46^{\mathrm{b}}$ & \\
\hline
\end{tabular}

OG ; Ongole Grade; FGH: Fries Holland Grade; *) mean based on breed type; **) mean based on each treatment; values followed by different superscript at the same column $(*)$ or row $(* *)$ show significantly different at $5 \%$

Table 3. Breed and Treatment Effect on Dry Matter Consumption (\%)

\begin{tabular}{ccc}
\hline \multirow{2}{*}{ Feed quality } & \multicolumn{2}{c}{ Dry matter consumption (\%) } \\
\cline { 2 - 3 } & OG Breed* & FHG Breed* $^{*}$ \\
\hline High-quality feed & $51.1^{\mathrm{b}}$ & $33.9^{\mathrm{a}}$ \\
Low-quality feed & $37.4^{\mathrm{a}}$ & $48.3^{\mathrm{b}}$ \\
\hline
\end{tabular}

*) The both value followed by a different superscript at the same column showed significantly different at $5 \%$

Table 4. Feeding efficiency on FHG and OG bulls

\begin{tabular}{lccc}
\hline \multirow{2}{*}{ Feed quality } & \multicolumn{3}{c}{ Feeding efficiency } \\
\cline { 2 - 4 } & OG & FHG & Mean $\left.{ }^{* *}\right)$ \\
\hline High-quality feed & 0.011 & 0.068 & $0.035 \pm 1.1^{\mathrm{a}}$ \\
Low-quality feed & 0.052 & 0.081 & $0.064 \pm 0.9^{\mathrm{b}}$ \\
Mean $\left.{ }^{*}\right)$ & $0.031^{\mathrm{a}}$ & $0.074^{\mathrm{b}}$ & \\
\hline
\end{tabular}

*) mean based on each treatment; **) mean based on breed type; both values followed by a different superscript at the same row $(*)$ or column $(* *)$ showed significantly different at $1 \%$. 
the $\mathrm{GH}$ locus was determined as 0.455 or $45.5 \%$ (A allele frequency or p was 0.35 and B allele frequency or $\mathrm{q}$ was 0.65 ) (Table 5). These numbers indicate a relatively high degree of polymorphism.

\section{GH Genotype Interaction on Dry Matter Feed Consumption and Digestibility}

GH genotype and interaction between genotype and breed did not significantly affect dry matter consumption. Different feed quality did not affect the feed dry matter consumption. On the contrary, GH genotype affected the consumption significantly $(\mathrm{P}<0.05)$, even though the interaction between treatment and genotype did not produce a significant difference to dry matter consumption (Table 6). Based on our results, the GH-AA genotype has the potential to be a genetic marker since, for both kinds of feed, the bulls with GHAA consumed a higher dry matter than both GH$\mathrm{AB}$ and GH-BB bulls. The interaction between breed and genotype have a significant result $(\mathrm{P}<0.05)$ with respect to dry matter consumption. Treatment and GH genotype also interact significantly $(\mathrm{P}<0.05)$ with dry matter digestibility (Figure 1).

Table 5. Genotype Frequency of Growth Hormone

\begin{tabular}{cc}
\hline Genotype & Frequency (\%) \\
\hline AA & 12.25 \\
AB & 45.5 \\
BB & 42.25 \\
\hline
\end{tabular}

Influence of Breed, Feed type, and GH Genotype on Weight Gain

Breed had a significant effect $(\mathrm{P}<0.05)$ on mean daily weight gain, but feed treatment did not have any significant effect on daily weight gain. On the other hand, GH genotype nearly had a significant effect $(\mathrm{P}<0.05)$ on daily weight gain. The interaction between breed and genotype or between treatment and genotype was not significant for mean daily weight gain from the 1st weighing to the 4th weighing (Table 7).

\section{DISCUSSION}

Based on this research, Ongole Grade (OG) bulls are almost less heavy compared with Fries Holland Grade (FHG). These data are related to the dry matter consumption which is proportional to its body weight. Faverdin et al. (2017) also exhibited that body size and body frame is positively related to the feeding consumption and milk production in dairy cattle. The data in this study; however, contradict the current understanding that $\mathrm{OG}$ bulls have the best temperature adaptability due to their low basal metabolism rate. In addition, OG bulls are able to convert high crude fiber feed into high-quality beef via its symbionts in the omasum. Therefore, they have the ability to utilize high crude protein better than other breeds.

There was a tendency for OG bulls to gain a lower amount of weight on a daily basis than HFC bulls. Low-quality feed had a significant effect on body weight first and second week but highquality feed caused the bulls to gain significant weight by the third week. The bulls' adaptation to feeding during the first days may account for these results. OG bulls showed better growth after high-quality feed treatment after 3 weeks. This

Table 6. The Influence of Breed, Feet Type and GH Genotype on Feed Consumption

\begin{tabular}{|c|c|c|c|c|c|c|}
\hline \multirow{2}{*}{ Genotype } & \multicolumn{3}{|c|}{ Breed type } & \multicolumn{3}{|c|}{ Feed quality } \\
\hline & $\mathrm{OG}$ & FHG & Mean * & High & Low & Mean * \\
\hline $\mathrm{AA}$ & 6.07 & 10.25 & $7.81 \pm 1.8^{b}$ & 8.79 & 10.91 & $9.58 \pm 2.7^{b}$ \\
\hline $\mathrm{AB}$ & 1.51 & 8.76 & $5.74 \pm 2.3^{\mathrm{a}}$ & 6.27 & 5.29 & $5.74 \pm 1.7^{\mathrm{a}}$ \\
\hline $\mathrm{BB}$ & 5.65 & 9.54 & $7.27 \pm 1.2^{b}$ & 5.74 & 6.74 & $6.41 \pm 3.1^{\mathrm{a}}$ \\
\hline Mean $* *$ & $5.23^{\mathrm{a}}$ & $10.52^{b}$ & & $7.70^{\mathrm{a}}$ & $7.13^{\mathrm{a}}$ & \\
\hline
\end{tabular}

The number followed by a different superscript in the same column $(*)$ and row $(* *)$ is significantly different at $5 \%, \mathrm{OG}=$ Ongole Grade, $\mathrm{FHG}=$ Fries Holland Grade 


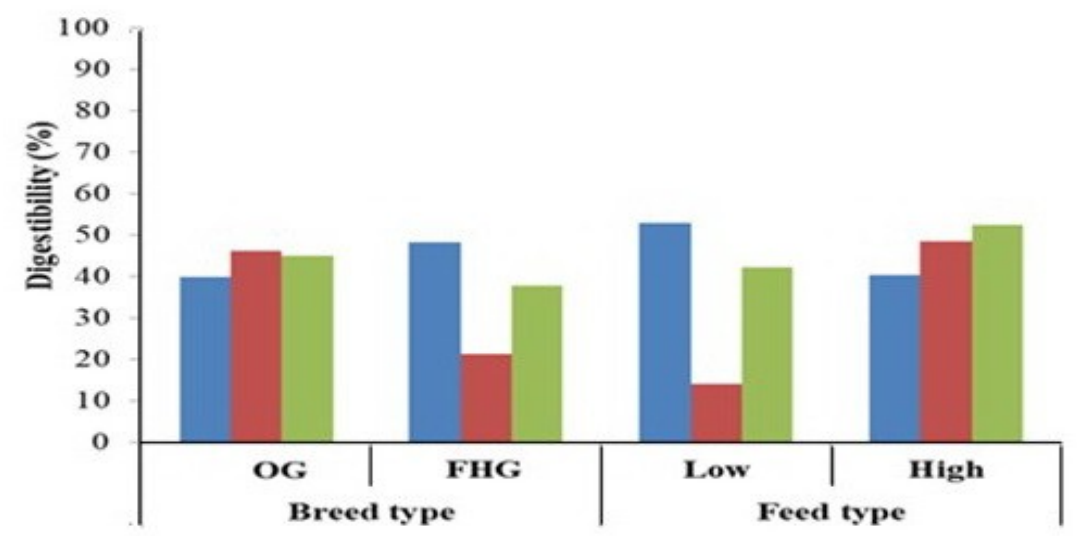

Figure 1. Breed and feed type influence and interaction with genotype (AA/ blue bar, AB/ red bar, BB/ green bar) on digestibility.

Table 7. The Influence of Breed and Feed Type and GH Genotype on Weight Gain

\begin{tabular}{|c|c|c|c|c|c|c|}
\hline \multirow{2}{*}{ Genotype } & \multicolumn{3}{|c|}{ Breed type } & \multicolumn{3}{|c|}{ Feed quality } \\
\hline & OG & FHG & Mean *) & High & Low & Mean * \\
\hline AA & 0.098 & 0.72 & $0.57 \pm 0.03^{c}$ & 0.44 & 0.77 & $0.57 \pm 0.9^{\mathrm{c}}$ \\
\hline $\mathrm{AB}$ & 0.13 & - & $0.13 \pm 0^{\mathrm{a}}$ & 0.13 & 0.39 & $0.25 \pm 0.1^{\mathrm{a}}$ \\
\hline $\mathrm{BB}$ & 0.21 & 0.64 & $0.32 \pm 0.5^{\mathrm{b}}$ & 0.18 & 0.39 & $0.32 \pm 0.2^{b}$ \\
\hline Mean ** & $0.19^{\mathrm{a}}$ & $0.69^{b}$ & & $0.30^{\mathrm{a}}$ & $0.48^{\mathrm{b}}$ & \\
\hline
\end{tabular}

indicated that $\mathrm{OG}$ bulls were starting to convert feed into beef after 3 weeks of treatment.

The GH-BB genotype can be considered as a genetic marker for both breeds. In addition, GH$\mathrm{AB}$ and $\mathrm{GH}-\mathrm{BB}$ can be utilized as genetic markers of dry matter digestibility in OG bulls. Furthermore, GH-AA can be considered as well, but only in HFC breeds in addition to GH-BB genotype. This genetic variation is due to the different ancestry for each breed (Othman et al., 2015).

\section{CONCLUSION}

There were a potency of GH-AA and GH$\mathrm{BB}$ as genetic markers for growth in both the $\mathrm{OG}$ and FHG breeds with high polymorphism, regardless of the feed quality. FHG bulls grew better, consumed higher dry matter, and fed more efficiently than OG bulls. The low-quality feed was digested more efficiently, thus producing higher daily weight gain. It was concluded that bulls with GH-AA and GH-BB genotypes have better mean daily growth than the GH-AB genotype; so both genes have the potential to serve as genetic markers for the growth of FHG and OG breed bulls, regardless of feed quality.

\section{ACKNOWLEDGMENTS}

The authors thank to University of Brawijaya for and Beef Cattle Research Centre Grati, Pasuruan East Java for facilitating this research

\section{REFERENCES}

Amiri, S., B. Jemmali, J.M. Amine and H. Jeljeli. 2018. Assessment of growth hormone gene polymorphism effects on reproductive traits in Holstein dairy cattle in Tunisia. Arch. 
Anim. Breed. 61: 481-489

Colditz, I.G. and C. Hine. 2016. Resilience in farm animals: biology, management, breeding, and implications for animal welfare. Anim. Prod. Sci. 56:1961-1983.

Faverdin, P., A. Charrier and A. Fischer. 2017. Prediction of dry matter intake of lactating dairy cows with daily live weight and milk production measurements. European Conference on Precision Livestock Farming (ECPLF), Nantes, France, September 2017. P. 35-44.

Ferraz, J.B.S and P.E. de Felicio. 2010. Production systems - An example from Brazil. Meat Science. 83:238-243

General Directorate of Livestock. 2017. Statistik Peternakan dan Kesehatan Hewan (Livestock and Animal Health Statistics). Ministry of Agriculture of Indonesian. Jakarta.

Jakaria and R.R. Noor. 2011. Analysis on Alu-1 Growth Hormone (GHAlu-1) Gene in Bali Cattle. J. Indonesian Trop. Anim. Agric. 36(2):77-82.

Lehtonen, H. and X. Irz. 2013. Impacts of reducing red meat consumption on agricultural production in Finland. Agric. Food Sci. 22:356-370.
Nazli, M.H., R.A. Halim, A.M. Abdullah, G. Hussin and A.A. Samsudin. 2018. Potential of feeding beef cattle with whole corn crop silage and rice straw in Malaysia. Trop. Anim. Health Prod. 50: 1119-1124.

Oldenbroek, K. and L. van der Waaij. 2014. Animal breeding and genetics for $\mathrm{BSc}$ students. Centre for Genetic Resource and Animal Breeding and Genomics Group. Wageningen University. Netherlands.

Othman, O.E., S.S. Alam, H.A.M. Abd El-Kader and O Abd-El-Moneim. 2015. Genotyping of growth hormone gene in Egyptian small ruminant breeds. Biotechnology. 14:136141.

Pribadi, L.W., S. Maylinda., M. Nasich and S. Suyadi, 2015. Reproductive efficiency of Bali cattle and it's crosses with Simmental breed in the lowland and highland areas of West Nusa Tenggara Province, Indonesia. Livestock Research for Rural Development. 27(2).

Purbowati, E., W.S. Dilaga and N.S.N. Aliyah. 2005. Penampilan Produsi Sapi Peranakan Ongole dan Peranakan Limousine Jantan dengan Pakan Konsentrat dan Jerami Padi Fermentasi. Proceedings, National Seminar AINI V, 10 August 2005, pp. 99-109. 